\title{
Design and Implementation of Music Teaching Platform in College Based on Android Mobile Technology
}

\author{
http://dx.doi.org/10.3991/ijet.v11i05.5686 \\ Juan Tong \\ Henan Polytechnic, Zhengzhou, Henan, China
}

\begin{abstract}
-multi-media teaching is the trend for improving teaching approach, yet what is currently prevalent in university education is its low interaction and inefficient knowledge absorption level. According to the characteristics of multimedia teaching, this paper discussed application of informational teaching resources in university music teaching and explored ways to improve the quality of music teaching. This paper took chorus conduction in university music course as experiment subject, through analysis of teaching resources based on Android system and its design principle, analysis of teaching machine based on android system covered various aspects which included teaching process, resources interface, interactive approaches, and effect assessment. The paper used methods like interview, statistics and comparing the efficiency difference before and after its application. Through the research, we found that optimized android teaching system can improve students' scores and overall quality level, which provides ideas and data backup applications of modern teaching resources in university music course.
\end{abstract}

Index Terms-Android, music course, multimedia technology, quality education

\section{INTRODUCTION}

Multimedia teaching with its own integrated, controlled, interactive features has been widely used in modern teaching [1]. Application of multimedia technology in teaching can help or partly replace the role of teachers. Multimedia teaching has notable features: a rich audiovisual experience can effectively stimulate interest; friendly interactive environment can mobilize the enthusiasm of the students; a wide range of information sources can broaden the students ' horizons; the new way of teaching is in accordance with brain cognitive pattern; various channels can give students more choices [2]. Development of mobile internet in recent years provides an advanced technical base for the improvement of teaching model. The Android system is a free and open source operating system led and developed by GOOGLE and the Open Handset Alliance. It is the first complete, open, and free intelligent mobile development platform. Android is the most mainstream operating system for tablets at home and abroad, and has grown to Android4.2.2 in 2013. Its ease of use has been recognized by the general public. It is the preferred platform for mobile intelligent terminal [3].

Currently, Android's teaching resources can be built on the Android platform. By combing with multimedia technologies and using the most widely used Android mobile platform, contact between teachers and students can be built on mobile phones and tablet computers to give full play to role of computer teaching resources and greatly improve the quality of teaching [4]. Yan and Zhang [5] and others researched and designed interactive teaching response system on android development platform which is a new mode of teaching between teachers and students in the classroom teaching. System contains the teacher-side computer and student's cell phones, teacher's uses multimedia in computer to raise questions, and students use cell phone answering software to submit answers. Teaching computer and student's mobile phone transmit information by wireless communication, and would display answering status with statistics in real time. The teacher would pace his teaching according to the status to achieve teaching interaction. Lu et al. [6] designed teaching interactive feedback system based on the VSTO technology and Android phones. Experiment shows that the system has characteristics such as no additional hardware investment, ease of use, high reliability and multiple functions. It is suitable for the current teaching in university. Bian et al. [7] designed and developed a "teaching assistant system" based on Android smart phone. Use wireless capabilities of Android smart phones to build a small-size LAN to sign in. The software also simplify in time assignment submission and signing in process. Andrus and Nieh built a virtual laboratory based on Android teaching system, which allows distributed version control, and live demonstrations, giving students hands-on Android experience with minimal computing infrastructure. We have used these Android kernel programming projects and the Android virtual lab to teach an introductory operating systems course. Teaching practices show that more than $80 \%$ students surveyed prefer to use Android and most of the students liked the Android to the traditional desktop development [8]. Damevski et al. by using the popular Android platform, enabled students successfully constructed and applied the CPS (Cyber-Physical Systems). Experiments think that this system can enhance the teaching effect, indirectly improve the student's intelligence and ability to understand the learned knowledge [9].

Music is a discipline with very strong practicality, teaching objectives of music course in colleges requires not only improve students ' professional accomplishments, but also should help the students to create a good art environment for quality education. Advanced educational 
technologies optimally integrate rich professional resources in graphic, audio and video with teaching. Compared with other subjects, music teaching equipment needs constant upgrade and improvement. There is an urgent need to update and progress. Music teachers Zhang and $\mathrm{Li}$ [10] discussed the importance and advantage of applying multimedia in music teaching to take advantage of its graphic-text characteristics. She put forward relevant measures for multimedia-aided teaching of Android system is going through rapid development with extremely high popularity. It has open platforms and user-friendly features. It is suitable for university music course teaching. There are few researches on application of android teaching system for music course in domestic academic community. Reports pointed out that: among equipment using Android (Android) system, only three third party play devices have EQ regulation function, the original media play device does not allow EQ regulation of the audio signal on media file, therefore, if Android equipment did not install third party play device, it won't be able to regulate EQ (Equalizer) for audio. In particular, when playing a video, EQ adjustments on audio through a third party player can not be achieved for better sound effects [11].

There are 2 innovations in this paper, one is through analysis of various buildings and designs of computer teaching resource platform based on android system and analysis of teaching requirements of college music course, design of computer teaching resources platform were achieved from four aspects: structure design, teaching process design, teachers and students interactive design, teaching assessment design, specific conclusion were obtained according to experiment and statistics; the other innovation is the method and device for regulation of audio on Android equipment, it can help original android media player achieve audio equalizer adjustment of media files, especially during video play, it can make up for the weakness of third-party players for lack of audio equalizer regulation and enhance sound effects of media files. It provides other researchers reference of optimization approach for computer teaching resource based on Android for and reference.

\section{COMPUtER TEACHING RESOURCES PlatFORM} BuILding AND Design BASEd ON THE ANDROID System

\section{A. Requirements analysis}

University music teaching course has its unique characteristics. Design and development of informational teach- ing resources suitable for the teaching of music at the university, understanding the resource requirements for the teaching of music at the university is necessary. Therefore, this paper took chorus conduction as experimental course and course students as subjects, adopted designbased research methods to conduct statistical analysis of experimental subjects and continuously improve teaching platform based on the statistical information to improve teaching practice. The chorus is a fundamental course in university music course. It emphasizes the participation and interaction between teachers and students in the classroom. It focus on interactivity and creativity, Androidbased informational teaching resources are in line with the features of this course, providing a better physical environment support for this study. Chorus conduction course structure is as figure 1.

Figure 2 shows structure diagram of web-based multimedia video system. It can be seen from the figure that the master computer is connected with multimedia system; the multimedia system is connected with local server through picture pick-up system and recording system; LAN is connected with the local server; LAN can send data (including character, picture, video and audio etc.) to personal computer via multimedia video system. Internet is connected with the local server through the switch, and can send data to personal computer through multimedia video system. In the whole state, for a service territory, local server, LAN and video system are used to send media file to users. In addition, individual client can acquire multimedia resource through internet access.

\section{B. System structure and function design}

\section{1) System structure design}

Teaching machine based on Android platform offers functions such as teacher and student login, class interaction, teaching assessment and feedback after class. Therefore the system is divided into four modules: login module, teaching module, assessment module and feedback module. Login module includes verifying information and network transmission; teaching module is for questionand-answer exchanges of teachers and students; assessment module includes assignment view and rating function; feedback module is to realize information exchange between teachers and students. System structure diagram is as figure 2. Login Interface of Teaching Machine Based on Android is as figure 3 and 4.

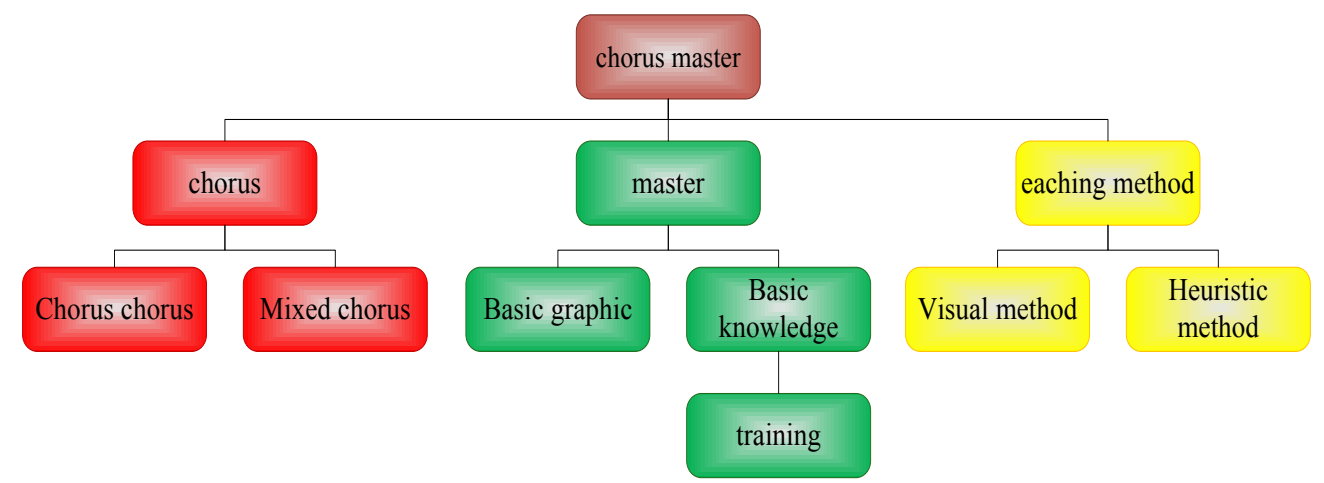

Figure 1. Chorus Conduction Courses Structure 
PAPER

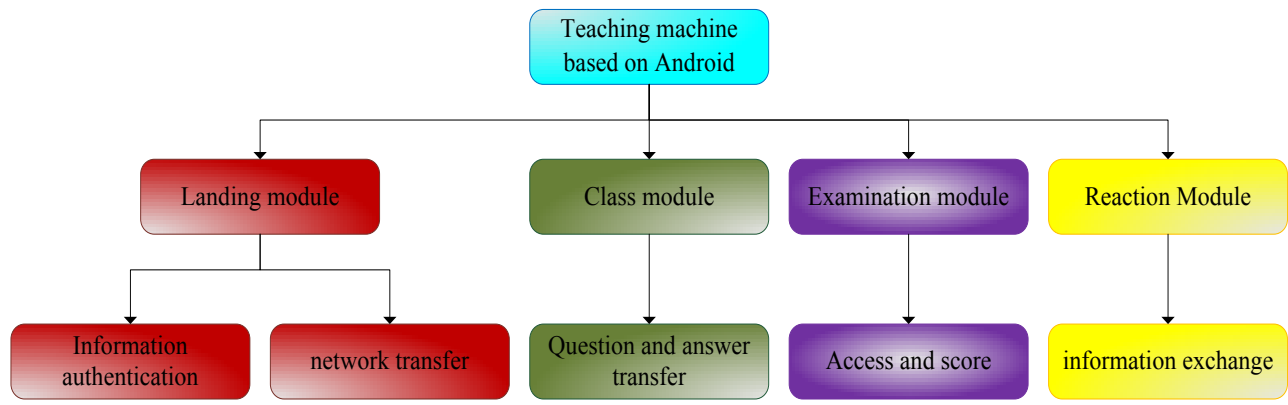

Figure 2. System Structure

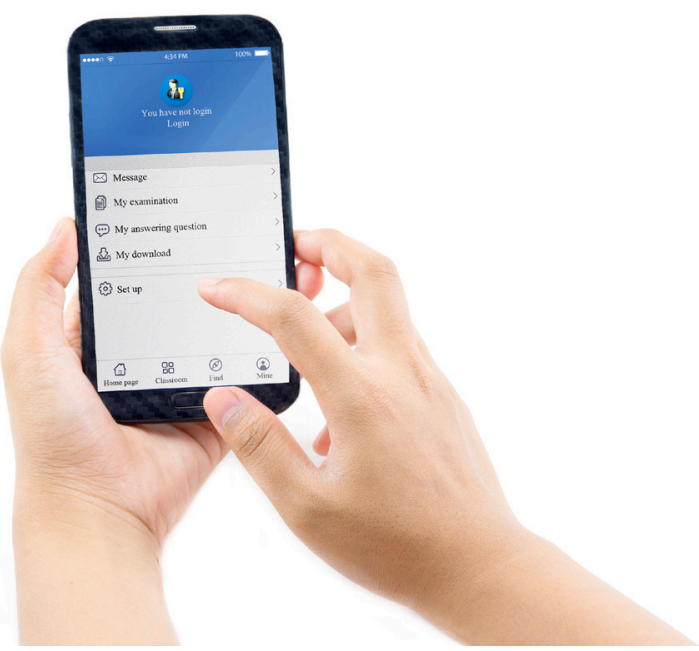

Figure 3. Login Interface of Teaching Machine (Mobile ) Based on Android

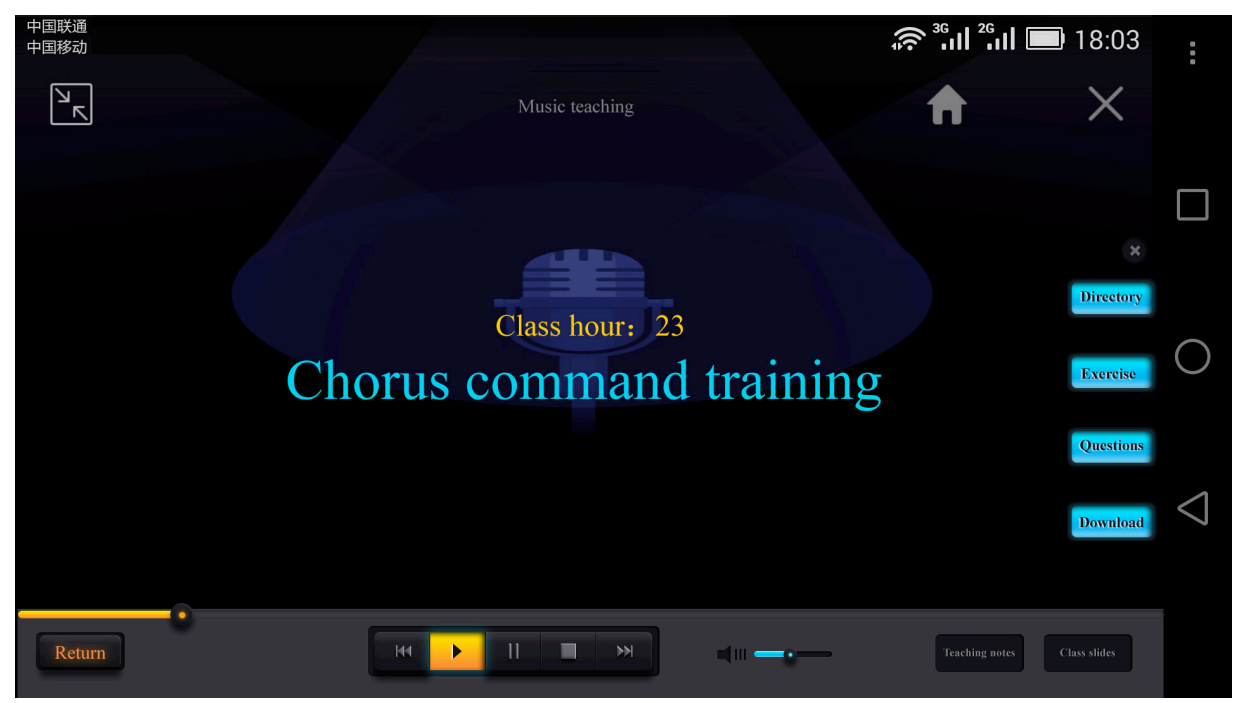

Figure 4. Login Interface of Teaching Machine (Tablet )Based on Android

\section{2) Audio regulation design in Android}

This system is used to add audio equalizer adjustment in Android devices. By receiving audio equalizer adjustment instructions, the system would decide, if the audio information is already encoded, then add audio equalizer adjustment in accordance with instructions received, and render output audio after the equalizer adjustment. (see figure 5)

3) Teaching process design

Application of multimedia teaching changes the role of teachers from the dominant role in teaching to the partici- pants, teachers have to adapt to this change [12]. New teaching model has many advantages, Android devices such as mobile phone and tablet can strengthen links between teachers and students and can combine in-class teaching with post-class teaching dynamically. Multimedia teaching increases classroom capacity and can add a lot of related knowledge. Taking chorus conduction as example, Android-based teaching machine can introduce a variety of musical types to enrich the students ' sense of rhythm and pitch, achieve coordination of various aspects such as speed, tone, pitch and others. 


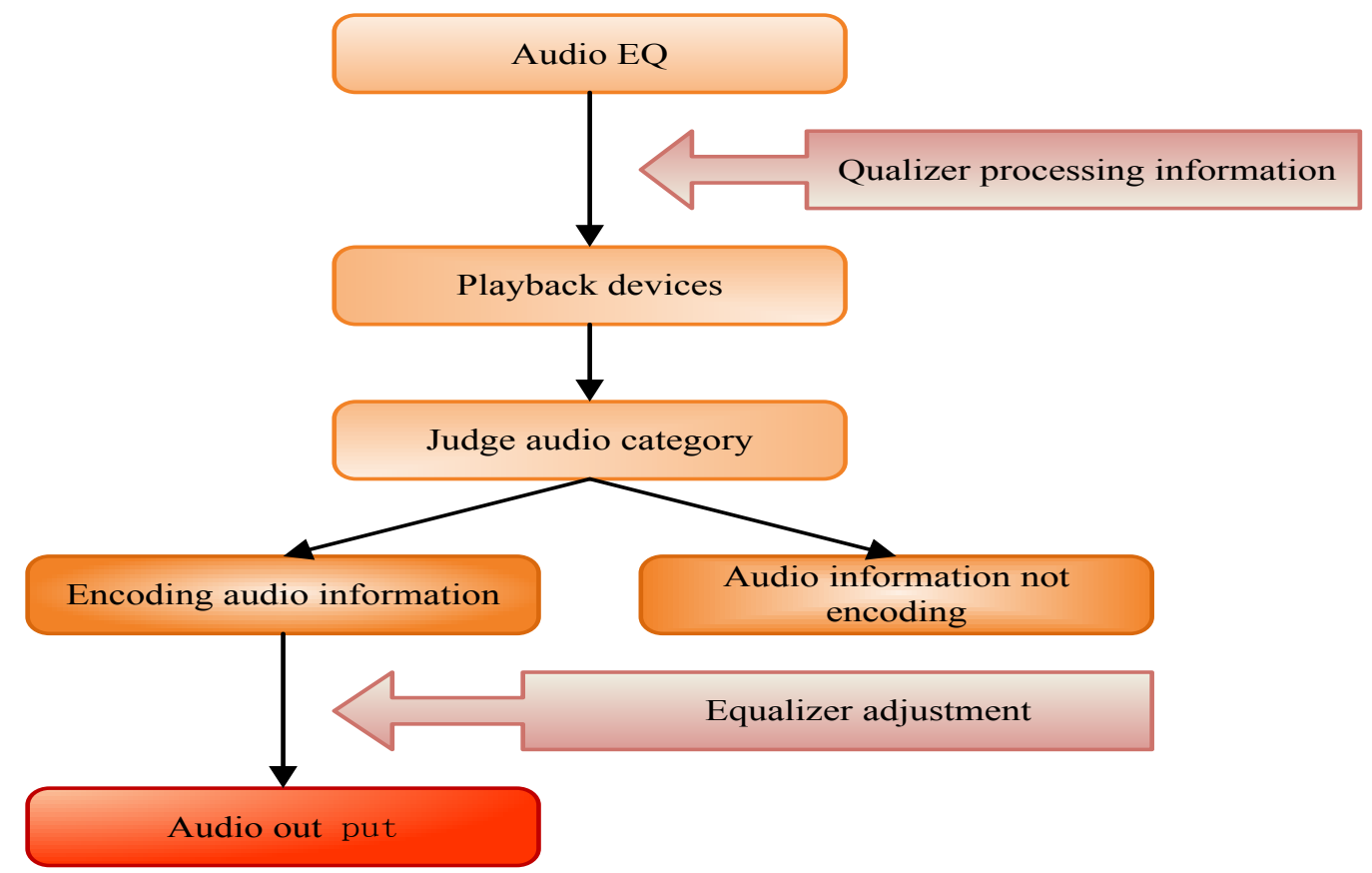

Figure 5. Audio Adjustment Design Sketch of Android Teaching System

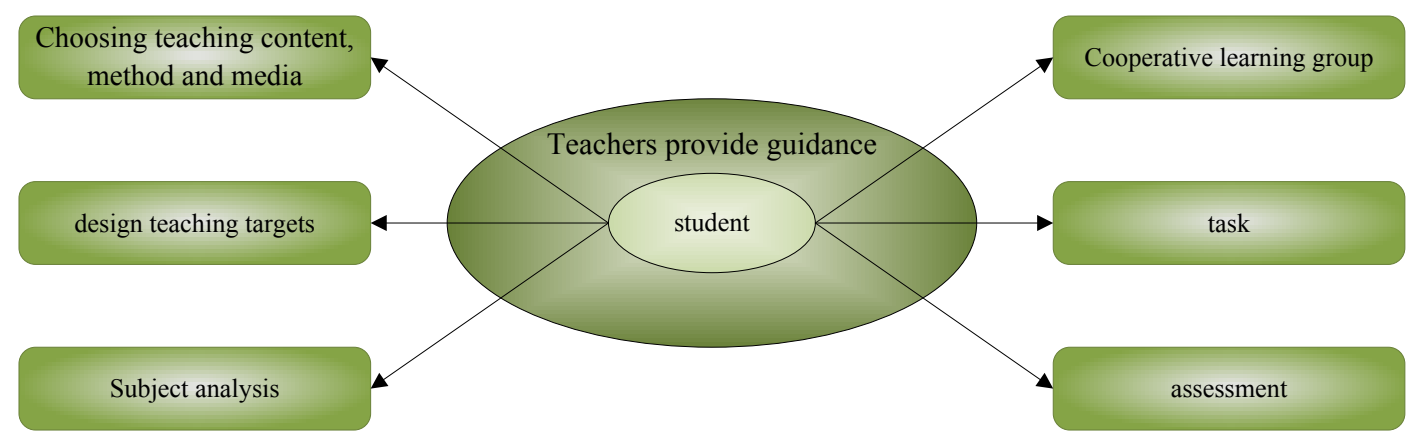

Figure 6. Teacher - student Interaction Design

According to the basic teaching process design patterns, using multimedia teaching design at home and abroad for reference, teaching process can be designed to meet the professional needs of the College music course. The teaching process should actively guide students to feel, experience, appreciate the art of music and their connotation so that students would learn knowledge in interaction and participation. For example, in the lesson of command gesture, apart from the teacher's demonstration, it emphasizes on independent cooperation and feedback in a timely manner to achieve better teaching results.

\section{4) Teacher - student interaction design}

According to the principle of interactive and emotional design, informational teaching resources based on Android are very expressive and has enriched teaching form for the university music. During the class, diagram, text, voice and graphic video, reality dub and action model can blend together, novel multimedia interactive test, reasonable graded evaluation feedback and various activities have changed monotone and boring teaching in the past: demonstration-typed multimedia course ware can present graphic, diagram, text and video intuitively, creating a colorful, video synchronized teaching situation that can be static and dynamic to provide unique audio-visual combined aesthetic experience for students; using CAI dynam- ic image demonstration which uses text adjustment, graphics transformation and color selection can simplify complex knowledge points. Through dynamic stimulus, it enhanced the teaching effect. Students in the study had more emotion, more thorough understanding of knowledge, which made up for inadequate teaching methods before, action courses such as the chorus conduction had better results. (see figure 6)

\section{5) Teaching assessment design}

According to the characteristics of the music course and the features of devices such as tablet computers, mobile phones and multimedia, teaching assessment can be in various forms such as graphic, video, text and voices, assessment forms should be more diversified and interactive, and students can have a better music experience.

Teaching evaluation includes assessment of students ' learning processes and learning outcomes, assessment result should be efficient and timely, achieve multi-layer interaction and realistic assessment. Evaluation of the learning process should be done in the course of teaching, target should be accurate operation by students; learning outcomes assessment includes timeliness assessment and summative assessment to track learning efficiency over a period of time. (see figure 7) 


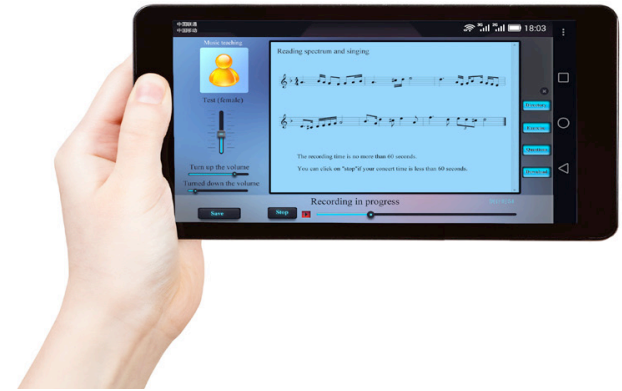

Figure 7. Score-reading Test Interface

\section{EFFECT ANALYSIS OF ANDROID-BASED TEACHING Machine Application In COLlege Music Course}

\section{A. Experiment scheme}

Teaching experiment started in October 2014 with a total of 72 class hours, its subject are junior students in music major. Experimental group and the control group were 130 people individually, teaching tasks were chaired by the author himself. Teaching content was the chorus conduction, teaching schedule remained consistent. Test was carried out upon completion of the teaching content.

\section{B. Experimental results}

42.31\% 与 27.69\%。As shown in Figure 9, in this experiment, $49.23 \%$ and $43.85 \%$ of students in the experimental group respectively choose the "willing or very willing to collaborate with classmates to complete teaching assignments from teachers"; while only $42.31 \%$ and $27.69 \%$ of the control group selected the same respectively. (see table I)

The Chi-square test, students in experimental group using Android music teaching have significantly higher general awareness and understanding than the control group $(\mathrm{P}<0.0001)$. (see table II)

Table III shows that $93.08 \%$ of students in experimental group thought that Android teaching system was helpful on music learning, only about $3 \%$ of students thought Android teaching system was not helpful or posing interference. The vast majority thought it was helpful $(\mathrm{P}<0.0001)$.

TABLE I.

COMPARISON OF STUdENTS’ COMMUNICATIVE ABILITy BetweEn Two Groups

\begin{tabular}{|l|c|c|c|}
\hline \multicolumn{1}{|c|}{ Group } & Very willing (\%) & Willing (\%) & Normal (\%) \\
\hline control group $(\mathrm{n}=130)$ & $36(27.69 \%)$ & $55(42.31 \%)$ & $39(30.00 \%)$ \\
\hline Experimental group $(\mathrm{n}=130)$ & $57(43.85 \%)$ & $120(49.23 \%)$ & $9(6.92 \%)$ \\
\hline
\end{tabular}

TABLE II.

Overall Comprehension Of Music From THe Two Groups Of Students By ANDroid TEACHING Methods

\begin{tabular}{|l|c|c|c|c|}
\hline \multicolumn{1}{|c|}{ Group } & Great help (\%) & Some help (\%) & Normal (\%) & No help (\%) \\
\hline control group $(\mathrm{n}=130)$ & $26(20 \%)$ & $81(62.31 \%)$ & $15(11.54 \%)$ & $8(6.15 \%)$ \\
\hline Experimental group $(\mathrm{n}=130)$ & $91(70 \%)$ & $22(16.92 \%)$ & $17(13.08 \%)$ & $0(0 \%)$ \\
\hline
\end{tabular}

TABLE III.

COMPARISON ON ASSISTANT EFFECT OF ANDROID LEARNING SYSTEM ON MUSIC LEARNING

\begin{tabular}{|c|c|c|c|}
\hline Group & Very helpful (\%) & Helpful (\%) & Interference (\%) \\
\hline Experimental group $(\mathrm{n}=130)$ & $121(93.08 \%)$ & $4(3.08 \%)$ & $5(3.85 \%)$ \\
\hline
\end{tabular}

\section{DISCUSSION}

Through this teaching practice, we can see that improved android teaching system is helpful in certain effect on music teaching, its specific merits are summarized as follow: first, this teaching facility can improve the quality of music teaching and cultivation of students' comprehensive qualities. Application framework of android teaching system can be reused. Its components can be replaced. It uses SQLite for structured data storage; multimedia supports a variety of audio and video formats, it supports sensor hardware such as camera, GPS, compass, and accelerometer. It meets the requirements of teaching of music major; second, the system can increase students ' communication skills with their peers. Multi-dimensional teaching platform built by the system shares mechanisms and ideas of providing a performance stage for students ' innovation ability, which has a positive role in the development of the teaching of music in university. Androidbased platform has a very strong interaction, which can enhance students ' communication skills with their peers and is helpful to achieve autonomous learning and group cooperation under the quality education requirements. In the new classroom, students are masters of the classroom. Relaxed atmosphere and flexible environment is conducive to exchanges among students, problems found in the study can be resolved in a timely manner; and, finally, this system can increase students ' awareness and overall understanding of music. Android-based music teaching machine gives new meaning to music teaching. Its rich contents in teaching can increase students' awareness and overall understanding on music major and helping students to have clear grasp of music curriculum framework of learning so that teaching materials can have more indepth analysis and processing. The whole process of teaching is artistic, rational and creative and students can also participate.

this paper analyzed features and needs of teaching practice combining android system with multimedia technology, it designed and achieved a preliminary courses practice platform based on android mobile system, the cloud service platform integrated android-based resources such as system schema, development environment, application environment and analysis tool. It also analyzed application of android-based teaching machine from aspects such as teaching process, resources interface, interactive way and 
effect assessment. This system can significantly improve students' learning results and quality level. We believe that such use and promotion of the teaching system is conducive to quality training of talent, in the meantime, the study also has problems that need to be further explored such as universality of experimental survey data and particularity of music major need to be further promoted, sustainability of design effectiveness needs further observation, etc..

\section{REFERENCES}

[1] Alawi G.A.A.A., \& Nasreen N., "Impact of E-Learning and Information and Communication Technology (ICT) on Learning in Taiz University," Multimedia Technology, vol. 2, no. 4, pp. 47-53, December 2013.

[2] Xian Y., \& Fan R., "The Application of Graphic Vision Information Processing in Multimedia Design," Lecture Notes in Information Technology, vol. 21, pp. 145, July 2012.

[3] Skelton G.W., Jackson J., Dancer F.C., "Teaching software engineering through the use of mobile application development," Journal of Computing Sciences in Colleges, vol. 28, no. 5, pp. 3944, May 2013.

[4] Kruse N.B., Veblen K.K., "Music teaching and learning online: Considering YouTube instructional videos," Journal of Music, Technology \& Education, vol.5, no. 1, pp. 77-87, May 2012. http://dx.doi.org/10.1386/jmte.5.1.77_1

[5] Yan H.W., Zhang L.F., Du S.W., Xu Y.L., "Research and Design on Teaching Response System Based on Android Development Patform," Journal of Nanjing Normal University (Engineering and Technology Edition), vol. 15, no. 1, pp. 30-34, April 2015.

[6] Lu Q., Luo W.S., Zhao M.W., "University Interactive Feedback Teaching System Based on VSTO Technology and Android
Phone," China Educational Technology \& Equipment, no. 12, pp. 26-28, August 2014.

[7] Bian J., Wang S.L., Liu C.S., Huang X.L., "Teaching Assistant System Based on Android," Practical Electronics, no. 4, pp. 072, April 2015.

[8] Andrus J., \& Nieh J., "Teaching operating systems using android," In Proceedings of the 43rd ACM technical symposium on Computer Science Education, ACM. pp. 613-618, February 2012. http://dx.doi.org/10.1145/2157136.2157312

[9] Damevski K., Altayeb B., Chen H., \& Walter D., "Teaching cyber-physical systems to computer scientists via modeling and verification," Proceeding of the 44th ACM technical symposium on Computer science education, ACM, pp. 567-572, March 2013. http://dx.doi.org/10.1145/2445196.2445365

[10] Zhang T.H., Li Q.W., "Application of Computer Multimedia Technology in Music Education in Independent Colleges," XIJUZHIJIA, no. 4, pp. 189-189. May 2015.

[11] Wang X.Y., "Design and Implementation of Mobile Learning Platform Based on Android System," Computer Knowledge and Technology, vol. 11, no. 19, pp. 70-73, September 2015.

[12] Liu J., Zhou Y.X., Zhu P.D., "Design and Application Research of Rural Music Tablet Teaching Resources - a Case Study of a Rural Primary School Music Curriculum in Wenshan Prefecture, Yunnan province, China," Distance Education in China, no. 7, pp. 6571, September 2015 .

\section{AUTHORS}

Juan Tong (Corresponding author) is a Lecturer in Henan Polytechnic, Zhengzhou 450046, Henan, China. Her research interests include Music and Dance, Art Aesthetics (tongjuan22@yeah.net)

Submitted 29 March 2016. Published as resubmitted by the author 30 April 20156. 